\title{
日本沿岸海域に分布する好気性コラーゲン分解細菌一II 単離稩菌の分類
}

\author{
笠 間 憲太郎・北御門 学
}

(1978 年 2 月 23 日受理)

\author{
Aerobic Collagenolytic Bacteria in the Coastal Area of Japan-II \\ Classification of Bacteria \\ Kentaro KaSAMA ${ }^{* 1}$ and Manabu KitamiKado*2
}

\begin{abstract}
Two hundred and thirty-six isolates of aerobic collagenolytic bacteria from the coastal areas of Japan were classified according to the criteria of the 8th edition of Bergey's Manual of Determinative Bacteriology. The great majority of these isolates (222 strains) were Gram negative, oxidase positive, single polar flagellation, asporogenous rod, and carbohydrate metabolism fermentative, produced acid but no gas from glucose, and were sensitive to 2,4-diamino6,7-diisopropyl pteridine and facultatively anaerobic. These morphological and biochemical characteristics suggested an assignment to genus Vibrio. The representative 10 strains which have high productivity of collagenolytic enzyme seem to belong to a species Vibrio parahaemolyticus (biotype 2) or to its allies. The members of genus Vibrio predominate among the collagenolytic bacteria which are distributed in natural coastal areas. The characteristics of several isolates ( 6 strains) were Gramnegative, oxidase positive, single polar flagellation, asporogenous rod, but carbohydrate metabolism oxidative, and were not sensitive to 2,4-diamino-6, 7-diisopropyl pteridine and aerobic, suggesting their assignment to genus Pseudomonas. The rest (8 strains) showed different characteristics, and could not be identified. The collagenolytic enzyme productivity of the isolates of genus Pseudomonas and of the unknown group was of no account.
\end{abstract}

前報1)で日本沿岸海域の海水，海底砂泥，プランクト ソ, 海産動植物には好気性（通性嫌気性を含む）コラー ゲン分解細菌が存在していることを明らかにし，多数の 分解細囷を単離したことを報告した。本報ではこれらの 単離紐菌を分類した結果について報告する。

\section{実験材料および方法}

供試細菌 前報りでュラーゲン分解細莯として単離し た 236 株の細菌である。

細菌の同定法 Bergey's Manual 第 8 版 ${ }^{2}$ 記載の同 定基準によつた。 BAIN と SHEWAN の同定图式 ${ }^{8)}$ を参考にした。形態, 運動性, グラム染色性は光学顕微 鏡て観察し，オキシダーセ試験は KovACs の方法4)，炭 水化物代謝 (O/F medium) は Hugh-LEIFSON の方 法o), 2, 4-diamino-6, 7-diisoproyl pteridine (Vibrio- static agent 0/129) に対する感受性は SHEWAN 5の方 法 $^{(3)}$ によつた。その他の生理試験は通常法によつた。な お，成育温度試䥐，塩分要求試験などの特殊な場合を除 いて，培地の食塩濃度は 3\%にになよらに調整し，培 掏は $25^{\circ} \mathrm{C}$ で行つた。また, DNAのGC 含量はWANG と HASHAGEN の方法7゙によつて測定し, 一部の細菌の ベん毛観察には電子顕徽鏡を使用した。

使用薬品 前報”之同じ

\section{実 験 結 果}

単離勫菌の属組成全単離細菌 236 株中 228 株 (96.6\%) といら大多数がグラム陰性，オキシダ一ゼ陽 性, 単極毛を有する非胞子形成の桿菌であつた。これら の細菌はさらに二つの groupに分けられた。すなわち, 222 株の細菌は第 $1 の$ group に属し，炭水化物代謝は

*1 九州大学農学部水産学科 (Department of Fisheries, Faculty of Agriculture, Kyushu University 46-04, Hakozaki, Higashi-ku, Fukuoka 812, Japan).

現所属長崎大学水学部 (Present address: Faculty of Fisheries, The University of Nagasaki, Bunkyomachi 852, Japan).

*2 九州大学農学部水産学科 (Department of Fisheries, Faculty of Agriculture, Kyushu University 46-04, Hakozaki, Higashi-ku, Fukuoka 812, Japan). 
発醉的，ダルコースから酸を産生し，ガスは非産生， Vibriostatic agent $0 / 129$ に対して感受性がある, Vibrio 属の細菂群と考兄られた。コラーダン分解醭素産生能の 大さい緗菌は，前裉りで示した代表的な酵素産生株であ
る 10 株の緗菌も含めて，すべてこの group に属して いた。第 2 group に属する細菌は少なく，わずかに 6 株のみであり，炭水化物代謝は酸化的，Vibriostatic agent $0 / 129$ に奶与る感受性はなく，Pseudomonas 属

Table 1. Genera assignment of 236 isolates of collagenolytic bacteria

\begin{tabular}{llcc}
\hline Group & \multicolumn{1}{c}{ Main characteristics } & $\begin{array}{c}\text { Conceivable } \\
\text { genus }\end{array}$ & $\begin{array}{c}\text { Number of } \\
\text { isolates }\end{array}$ \\
\hline & $\begin{array}{l}\text { Gram negative, asporogenous rod, motile by a single polar } \\
\text { flagellum, carbohydrate metabolism (O/F medium) fermenta- } \\
\text { tive, catalase positive, oxidase positive, acid but no gas } \\
\text { from glucose, sensitive to 2, 4-diamino-6, 7-disopropyl } \\
\text { pteridine, facultative anaerobic }\end{array}$ & Vibrio & $\begin{array}{c}222 \\
(94.1 \%)\end{array}$ \\
\hline & $\begin{array}{l}\text { Gram negative, asporogenous rod, motile by a single polar } \\
\text { flagellum, carbohydrate metabolism (O/F medium) oxida- }\end{array}$ & Pseudomonas & $\begin{array}{c}6 \\
\text { tive, catalase positive, oxidase positive, not sensitive to 2, }\end{array}$ \\
4-diamino-6, 7-diisopropyl pteridine, aerobic & & Unknown & 8 \\
\hline Group 3 & Various characteristics & $(3.4 \%)$ \\
\hline
\end{tabular}

Table 2. Morphological, cultural and biochemical characteristics of representative ten isolates*

\begin{tabular}{|c|c|c|c|c|}
\hline \multicolumn{3}{|c|}{ Morphology } & \multicolumn{2}{|l|}{ Biochemistry } \\
\hline \multicolumn{3}{|c|}{ Trait Type } & Test & Reaction \\
\hline \multicolumn{3}{|c|}{ Form $\quad$ Rod with rounded ends } & Lecithinase (egg york) & + \\
\hline \multicolumn{3}{|c|}{ Size $\quad 0.5$ to 0.8 by 1.0 to $2.0 \mu \mathrm{m}$} & Hydrogen sulfide production & - \\
\hline \multicolumn{3}{|c|}{ Motility $\quad$ Motile } & Kovacs' oxidase & + \\
\hline \multicolumn{3}{|c|}{ Flagellum A single polar flagellum } & Catalase & + \\
\hline \multicolumn{3}{|c|}{ Spore $\quad$ Non-forming } & Acid from arabinose & - \\
\hline \multicolumn{3}{|c|}{ Gram stain Negative } & glucose & + \\
\hline \multicolumn{3}{|c|}{ Culture } & inositol & - \\
\hline \multirow{4}{*}{$\begin{array}{l}\text { Method } \\
\text { Agar plate } \\
\text { Agar slant } \\
\text { Broth }\end{array}$} & \multicolumn{2}{|l|}{ Appearance } & mannose & + \\
\hline & \multicolumn{2}{|l|}{ Grayish white, swarmihg } & salicin & - \\
\hline & \multicolumn{2}{|l|}{ Grayish white, swarming } & sucrose & + \\
\hline & \multicolumn{2}{|l|}{ Pellicle, turbid, sediment } & Starch hydrolysis & + \\
\hline \multicolumn{3}{|c|}{ Biochemistry } & Growth without added $\mathrm{NaCl}$ & + \\
\hline & Test & Reaction & in $10.0 \% \mathrm{NaCl}$ & + \\
\hline \multicolumn{3}{|c|}{ Indole production } & Growth at $5^{\circ} \mathrm{C}$ & - \\
\hline \multicolumn{2}{|c|}{ Methyl red } & - & at $37^{\circ} \mathrm{C}$ & + \\
\hline \multicolumn{2}{|c|}{ Voges-Proskauer } & + & at $42^{\circ} \mathrm{C}$ & + \\
\hline \multicolumn{2}{|c|}{ Citrate utilization } & + & Møller's media: & \\
\hline \multicolumn{3}{|c|}{$\begin{array}{l}\text { Sensitivity to 2, 4-diamino-6, 7-diisopropyl } \\
\text { pteridine (saturated) }\end{array}$} & Arginine-alkaline & - \\
\hline \multicolumn{2}{|c|}{ Sensitivity to novobiocin $(2 \mu \mathrm{g})$} & + & $\begin{array}{l}\text { Lysine decarboxylase } \\
\text { Ornithine decarboxylase }\end{array}$ & + or $-* *$ \\
\hline \multicolumn{2}{|c|}{ Gelatin liquefaction } & + & Luminescence & - \\
\hline \multicolumn{2}{|c|}{ Casein hydrolysis } & + & Laiminestice & \\
\hline \multicolumn{2}{|c|}{ Tween 80 hydrolysis } & + & GC ratio of DNA & $42-46 \%$ \\
\hline
\end{tabular}

* See Table 2 in the previous paper ${ }^{1)}$.

** Six isolates (strains No. D-99, D-8, D-65, D-100, D-97, D-106), positive; Four isolates (strains No. B-92, B-25, C-93, B-42), negative. 


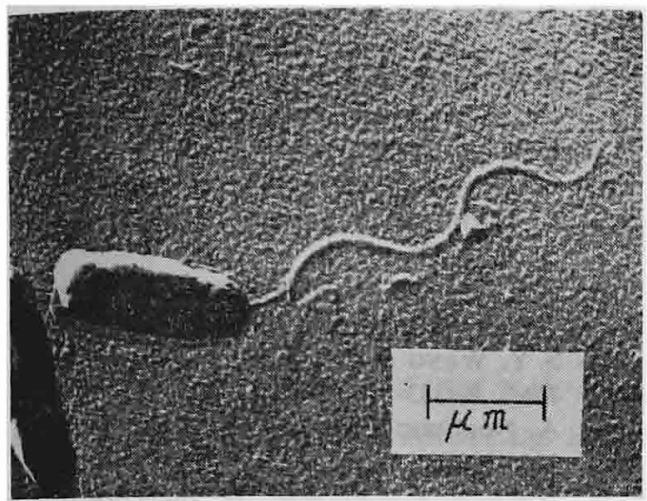

Fig. 1. Electron micrograph of No. 92 strain of Vibrio sp. $\mathrm{Cr}$ shadowing.

の細菌群と考えられた。この group の細菌のコラーケ゚ 㸮解酵素産生能は小さく, 第 1 の group の最下位の ものと同程度に過ぎなかつた。全単離細菌の中にはこの 他に，8株ではあつたが形態や生理的諸性質が不明膫な ために同定できない group があつた。しかし，この group の細菌のコラーゲン分解酵素産生能はいずれも小 さく，前記第 2 group のものと同程度であつた。

以上の結果をまとめて Table 1 に示す。

Vibrio 属細菌の諸性質 本属の細菌が 日本沿岸海域 に分布するコラーゲン分解細菌の厦占菌であると考えら れるので, 前報1) で示したュラーゲン分解酵素産生能が 大きい上位 10 株の細菌を対象として, 諸性質を詳細に 検討した。その結果は, 供試した 10 株の細菌間でオル ニチン脱炭酸反応が 6 株は陽性であり 4 株は陰性という 不一致が認められたが，検討した範囲内で，その他の諸 性質はすべて同一であつた。これらの細菌の諸性質を Table 2 に示し, コラーゲン分解酵素産生能が全単離 細菌中最大である B-92 株の電顕像を Fig. 1 亿示す。

\section{考察}

本研究の結果から, 日本沿岸海域に分布する好気性 (通性婎気性を含む) コラーゲン分解細菌はVibrio 属 とPseudomonas 属との細菌であり, しかもその大多数 が前者であると推察される。コラーゲンは海域や陸上の 種々の動物体に含まれ, 自然界に広く存在しているたん 白質であるにもかかわらず，沿岸海域におけるその分解 細菌が主としてVibrio 属の細菌に限定されることは, 陸上の分解細菌が主として Clostridium 属のものに限定 される8)ことを考え合わせると，興味深いことである。

単離細菌中, コラーゲン分解酵素産生能の大きい上位 10 株の細菌を選んで諸性質を検討した結果は，オルニ チン脱炭酸反応性を除いて, 10 株とも同一の性質を示
した。オルニチン脱炭酸反応陽性の 6 株の諸珄質は, SHEWAN と V'ERON の執筆になる Bergey's Manual 第 8 版2) 記载の Vibrio parahaemolyticus (biotype 2) の諸性質と完全に一致しているのでこの species の細 菌であると決定できそうである。しかし，オルニチン脱 炭酸反応陰性の 4 株の細菌には欵問が残る。

Bergey's Manual 第 8 版党には $V$. parahaemolyticus 以外にもVibrio 属の species としてV. cholerae, $V$. anguillarum, $V$. fischeri, $V$. costicola 4 species の 記載がある。しかしながら，オルニチン脱炭酸反応陰性 の上記 4 株の単離細菌を $V$. parahaemolyticus 以外の species に帰属させることは無理なようである。 $V$. cholerae は単離細菌のように培地中に食塩の添加がな ければ増殖できない細菌ではないし，広範围の日本沿岸 に四季を通じて分布している細菌がコレラの病原菌であ る筈もない。単離細菌と $V$. anguillarum とは好塩性の みならずクェン酸塩利用, アルギニン培地のアルカリ化 などの性質に相違がある。V. fischeri は好塩細菌であ り, 生息場も海水中と記載されているが, インドール産 生, メチルレッド反応, V.P. 反応, クエン酸塩利用, アルギニン培地のアルカリ化などの性質において，単離 細菌とは相違があり過ぎる。残る 1 species である $V$. costicola も好塩細菌であるが，インドール産生，クエ ン酸塩利用, カゼインとデンプンの加水分解, アルギ二 ソ培地のアルカリ化, リジン脱炭酸反応などの多くの性 質に相違がある。結局, オルニチン脱炭酸反応陰性の 4 株の細菌も Bergey's Manual 記載の 5 species の中で はV . parahaemolyticus (biotype 2) に最も近似した性 質を有すると考えざるをえない。BAIN とSHEWAN の 細菌同定に関する手引書 $\left.{ }^{3}\right)$ ように, Vibrio 属細菌の アミノ酸脱炭酸反応に関連しては, アルギニン培地のア ルカリ化とリジン脱炭酸反応のみを取り上げ，オルニチ ン脱炭酸反応の記載がない著書もありこの4 株の単離 細菌むV. parahaemolyticus biotype 2 か, あるいは その近縁細菌之考えるのが妥当のよらである。ただし， これらの細菌のオルニチン脱炭酸反応性が研究室に拈け る保存期間中に変化したのかどうかは不明である。

$V$. parahaemolyticus biotype 2 は食中毒原因細菌の 一つである biotype 1 の近縁細菌であるが，10\% 食塩 添加培地中での增殖, メチルレッド反応, V.P. 反応, アラビノースとシュクロースからの酸産生などの性質の 相違によつて型別され，食中毒とは無関係といら意見が 多い早。日本沿岸海域における分布も調查され，申ら ${ }^{10)}$ は本型の細菌は夏季の沿岸海域に多数出現してくること を示唆している。本研究においても、コラーケ゚ン分解細 菌は前報1)のように夏季の沿岸海域に多数認められた。 本研究においては単離細菌の分類上の位置に関する詳 
紐な検討は代表的な10 株の細菌についてのみ行ない, 大多数のむのについては行つていない。しかしながら, Vibrio 属の単離細菌のすべてが好塩性であり，寒天培 地上で swarming の性貿を有し，その他の肉眼的観察 による諸性質む同一であるから，大多数の単離細菌は Table 2 に示した 10 株の細菌と同 species の細菌で あるかまたはその近緑の細菌であるらと推察される。

$$
\text { 文献 }
$$

1) 北御聞 学・笠間帻太郎：日水誌，44,883-886 (1978).

2) R. E. Buchanan and N. E. Gibbons: Bergey's Manual of Determinative Bacteriology, 8th ed. The Williams and Wilkins Co., Baltimore (1974).
3) N. Bain and J.M. Shewan: in "Identification methods for microbiologists" (ed. by B. M. Gibss and D. A. Shapton), Part B, Academic Press, London and New York, 1968, pp. 79-84.

4) N. Kovacs: Nature, 178, 703 (1956).

5) R. Hugh and E. Leifson: J. Bacteriol., 66, 24-26 (1953).

6) J.M. ShewaN, M. Hodgkiss, and T. Liston: Nature, 173, 208-209 (1954).

7) S. Y. WANG and J.M. HASHAGEN: J. Mol. Biol., 8, 333-340 (1964).

8) A. Nordwig: Adv, in Enzymol, 34, 155205 (1971)

9）坂䐀利一：食品衛生研究, 14, 76-79 (1964).

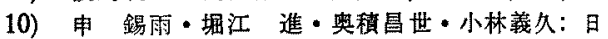
水誌, 42, 1041-1053 (1976). 